\title{
PENGARUH INDEPENDENSI, KOMPETENSI, DAN PROFESIONALISME AUDITOR TERHADAP PERTIMBANGAN TINGKAT MATERIALITAS DALAM PEMERIKSAAN LAPORAN KEUANGAN
}

\author{
Wiwi Idawati dan Roswita Eveline \\ Sekolah Tinggi Ilmu Ekonomi Indonesia (STEI) - Jakarta dan Universitas Bunda Mulia \\ Email:wiwiidawati@ymail.com danEmail:roswita_eveline@yahoo.com
}

\begin{abstract}
The aim of this research was to get empirical evidence about the effect of independence, competence, and professionalism of auditors on consideration of materiality level in the auditing of financial statements. This research uses causalcomparative study with primary data obtained using a questionnaire. The research sample was auditor on Public Accounting Firm (KAP) located in Central Jakarta and South Jakarta with a simple random sampling technique. Data analysis was used multiple linear regression, Based on this research, variable independence, competence, and professionalism of auditors were significant positive effect on considerations of materiality level in the auditing of financial statements simultaneously. Then partially, each variable has significant positive effect on considerations of materiality level in the auditing of financial statements too.
\end{abstract}

Keywords: Independence, Competence, Professionalism Auditor, Consideration of Materiality Level, and Auditing of Financial Statements.

Abstrak: Tujuan dari penelitian ini adalah untuk memperoleh bukti empiris pengaruh independensi, kompetensi, dan profesionalisme auditor terhadap pertimbangan tingkat materialitas dalam audit laporan keuangan. Penelitian ini menggunakan studi kausalkomparatif dengan data primer yang diperoleh dengan menggunakan kuesioner. Sampel penelitian adalah auditor di Kantor Akuntan Publik (KAP) yang berlokasi di Jakarta Pusat dan Jakarta Selatan dengan teknik sampling simple random sampling. Analisis data dilakukan menggunakan regresi linier berganda, Berdasarkan penelitian ini, variabel independensi, kompetensi, dan profesionalisme auditor yang berpengaruh positif signifikan terhadap pertimbangan tingkat materialitas dalam audit laporan keuangan secara bersamaan. Kemudian, masing-masing variabel memiliki pengaruh positif signifikan pada pertimbangan tingkat materialitas dalam audit laporan keuangan juga.

Kata kunci: Kemerdekaan, Kompetensi, Profesionalisme Auditor, Pertimbangan Tingkat Materialitas, dan Audit Laporan Keuangan.

\section{PENDAHULUAN}

Otoritas Jasa Keuangan (OJK) yang dahulu bernama Badan Pengawas Pasar Modal dan Lembaga Keuangan (Bapepam dan LK) menyatakan bahwa badan usaha publik wajib menyampaikan laporan keuangan berkala kepada OJK. Laporan keuangan tersebut wajib 
disertai dengan laporan hasil audit atas laporan keuangan oleh akuntan publik yang terdaftar di OJK. Artinya, setiap badan usaha yang go public atau masuk dalam Bursa Efek Indonesia pasti akan membutuhkan audit atas laporan keuangannya (Tjandrawinata dan Pudjolaksono, 2013). Dewasa ini berbagai pihak seperti: pemerintah, pemakai informasi keuangan dan pihak penyaji informasi keuangan telah memberikan perhatian secara serius terhadap kualitas audit. Pihak profesi akuntan publik juga telah menyatakan komitmen terhadap auditing yang berorentasi pada kualitas (Grant et al, 1996).

Audit atas laporan keuangan merupakan suatu bentuk jasa profesi yang dilakukan oleh kantor akuntan publik (KAP). Menurut Nirmala dan Cahyonowati (2013), profesi akuntan publik adalah profesi yang bertanggung jawab untuk menaikkan tingkat keandalan laporan keuangan. Salah satu jasa akuntan publik adalah memberikan informasi yang akurat dan dapat dipercaya untuk pengambilan keputusan bagi para pengguna. Seperti yang dikatakan Manita et al. (2011), tujuan dari audit seperti yang didefinisikan oleh standar IFAC (Federasi internasional akuntan) adalah untuk memungkinkan penggambaran pendapat atas keandalan opini yang disediakan oleh dokumen keuangan. Untuk mencapai tujuan ini, auditor menggunakan metodologi yang sesuai dengan standar audit. Kualitas aktual menunjukan tingkat risiko terjadinya kesalahan material dalam laporan keuangan yang daapt dikurangi oleh auditor, sedangkan persepsi kuantitas menunjukan tingkat kepercayaan para pengguna laporan keuangan terhadap efektifitas auditor dalam mengurangi salah saji material dalam laporan keuangan yang dibuat oleh manajemen ( Jackson et al, 2008).

Ada dua karakteristik terpenting yang harus ada dalam laporan keuangan adalah relevan (relevance) dan dapat diandalkan (reliable). Kedua karakteristik tersebut sangatlah sulit untuk diukur, sehingga para pemakai informasi membutuhkan jasa pihak ketiga yaitu auditor independen untuk memberi jaminan bahwa laporan keuangan tersebut relevan dan dapat diandalkan, sehingga dapat meningkatkan kepercayaan semua pihak yang berkepentingan dengan perusahaan tersebut (Singgih \& Bawono, 2010). Independensisi auditor penting dalam konteks kualitas audit karena audit independen sangat penting untuk kredibilitas dan integritas laporan keuangan. Kurangnya kemandirian mengganggu kemampuan auditor untuk melaksanakan penilaian audit yang obyektif dan mempengaruhi kepercayaan diri dalam proses audit (Susanti, 2013). Fungsi pokok akuntan publik adalah melakukan pemeriksaan umum atas laporan keuangan perusahaan dan memberikan opini atas kewajaran laporan keuangan setelah melakukan prosesur audit. Karena perannya yang sangat strategis, maka profesi akuntan publik di samping diawasi oleh organisasi profesi itu sendiri, juga diawasi oleh beberapa institusi pemegang otoritas (Agoes dan Ardana, 2013). Auditor yang independen dalam melakukan pekerjaannya tidak hanya berpaku pada satu kepentingan klien saja tetapi kepentingan banyak pihak diantaranya para pemegang saham dan para pemakai informasi auditan dan dalam meningkatkan kinerjanya dituntut untuk memiliki profesionalisme dalam melakukan audit atas laporan keuangan. Auditor yang professional belum cukup hanya memiliki sikap profesionalisme, auditor juga harus memiliki pengetahuan mendeteksi kekeliruan (Lestari \&Utama, 2013).

Generally Accepted Auditing Standards (Standar Audit yang Berlaku Umum) adalah standar otoritatif yang harus dipenuhi oleh auditor pada saat melakukan penugasan audit, merupakan media profesi audit untuk menjamin kualitas hasil audit (kualitas laporan hasil audit). Dimana kompetensi merupakan bagian pertama dari standar umum dalam standar audit, independensi merupakan bagian kedua dari standar umum dalam standar audit dan profesionalisme merupakan bagian ketiga dari standar umum dalam standar 
audit (Adrian, 2013). Halim Alamsyah (2011) menyatakan bahwa pada kasus PT. Bank Mega, Tbk,. KAP KPMG lalai dalam melaksanakan proses auditnya karena KPMG tidak menemukan adanya penggelapan dua dana nasabah, yaitu PT Elnusa, Tbk dan Pemkab. Batubara pada rentang 2009-2010 masing-masing sebesar Rp111 Milyar dan Rp80 Milyar. Seharusnya seorang auditor harus bisa menemukan kecurangan-kecurangan yang dilakukan baik disengaja maupun tidak disengaja oleh manajemen perusahaan, dimana seorang auditor harus memiliki kemampuan maupun keahlian teknis dalam memahami bisnis kliennya. Mc. Enroe et al (2001) menyatakan bahwa: "auditor and Investor perceptions of the expectation gap", dalam hal ini expectation gap menunjukan bahwa investor sebagai salah satu pemakai laporan keuangan memiliki harapan yang lebih atas pekerjaan yang dilakukan oleh akuntan publik. Maka dari itu auditor diharapkan memiliki persyaratan seperti yang dinyatakan dalam Pernyataan Standar Auditing yakni keahlian dan kompetensi (Singgih dan Bawono, 2010).

Tuanakotta (2014) yang mengatakan bahwa salah satu penyebab dari suatu gagal audit adalah rendahnya profesionalisme. Profesional yang menumpulkan kepekaan auditor terhadap kecurangan, baik yang nyata maupun yang berupa potensi, atau terhadap tandatanda bahaya (red flags, warnings signs) yang mengindikasikan adanya kesalahan dan kecurangan. Bambang (2011) menyatakan bahwa belum berkualitasnya audit di Indonesia dapat dilihat adanya temuan 3 (tiga) staf Badan Pemeriksaan Keuangan (BPK) yang menjadi penanggung jawab mengaudit skandal Bank Century tidak berkualifikasi auditor forensik dan tidak memilki Certified Fraud Examiner (CFE), Akibatnya audit forensik Badan Pemeriksa Keuangan (BPK) terhadap skandal Bank Century terutama menyangkut aliran dana talangan (bail out) milik negara sebesar Rp. 6,7 triliyun tidak terungkap.

Menurut Faux (2012), pengungkapan informasi material, salah satu masalah yang paling signifikan dalam akuntansi, adalah didasarkan pada gagasan bahwa materialitas merupakan pusat paradigma keputusan kegunaan dalam akuntansi. Gagasan materialitas mengandaikan kemampuan akuntan untuk menentukan apakah penilaian pada materialitas mempengaruhi keputusan pengguna. Untuk akhir ini, heuristik diukur telah digunakan untuk menentukan relevansi materialitas. Namun, heuristik kuantitatif atau ambang batas yang memberikan panduan tentang penilaian materialitas belum diadopsi secara global. Audsabumrungrat dan Sompong (2012) menyatakan pertimbangan materialitas menjadi penting bagi auditor karena akan berkaitan dengan evaluasi resiko, dimana pertimbangan inilah yang akan mempengaruhi cara-cara pencapaian tujuan audit, ruang lingkup dan arah pekerjaan terperinci serta disposisi kesalahan dan kelalaian. Pertimbangan auditor tentang materialitas merupakan masalah kebijakan profesional dan dipengaruhi oleh persepsi auditor tentang kebutuhan yang beralasan dari laporan keuangan (Minanda, 2013). Penetapan tingkat materialitas membantu auditor dalam merencanakan bukti yang cukup dalam proses pengauditan. Jika auditor menetapkan tingkat materialitas yang rendah, maka jumlah bukti yang harus dikumpulkan lebih banyak dalam proses pengauditan (Ekawati, 2013). Konsep materialitas penting selama proses audit, mulai dari perencanaan audit sampai pada mengevaluasi hasil pengujian audit. Pertimbangan profesional menentukan apa yang dianggap sebagai bahan pada setiap fase ini proses audit (Houghton et al., 2011).

Dalam membuat kebijakan mengenai tingkat materialitas, auditor biasanya menentukan terlebih dahulu mengenai batas nilai materialitas, sehingga hal ini dapat bermanfaat dalam menentukan apakah terdapat kekeliruan atau salah saji yang material atau tidak. Semakin kecil tingkat materialitas yang ditetapkan oleh auditor, maka auditor 
harus mencari bukti lebih banyak agar auditor memperoleh keyakinan atas audit yang dilakukan. Mengapa auditor harus mempertimbangkan dengan baik penaksiran materialitas pada tahap perencanaan audit, karena seorang auditor harus bisa menentukan berapa jumlah rupiah materialitas suatu laporan keuangan kliennya (Kinanti, 2013).

Berdasarkan latar belakang masalah dalam penelitian ini maka rumusan masalah dalam penelitian ini adalah untuk melihat bagaimana independensi, kompetensi dan profesionalisme auditor berpengaruh terhadap pertimbangan tingkat materialitas dalam pemeriksaan laporan keuangan; Adapun maksud dari penelitian ini adalah untuk menganalisis dan mengetahui pengaruh independensi, kompetensi dan profesionalisme auditor berpengaruh signifikan terhadap pertimbangan tingkat materialitas dalam pemeriksaan laporan keuangan.

Tujuan yang ingin dicapai adalah untuk mengetahui dan memperoleh bukti empiris pengaruh independensi, kompetensi, dan profesionalisme auditor terhadap pertimbangan tingkat materialitas dalam pemeriksaan laporan keuangan dari sisi pandang auditor, sehingga dapat dijadikan pedoman, bahan pertimbangan dan bahan referensi bagi para auditor dalam pelaksanaan proses audit terutama berkaitan dengan pertimbangan tingkat materialitas dalam pemeriksaan laporan keuangan.

\section{KAJIAN TEORI}

Independensi. Beberapa definisi terkait independensi, antara lain menurut Arens et al., 2013 menyatakan bahwa mengambil sudut pandang yang tidak bias dalam melakukan pengujian audit, evaluasi atas hasil pengujian dan penerbitan laporan audit. Auditor tidak hanya harus independensi dalam fakta (independence in fact) ada bila auditor benar-benar mampu mempertahankan sikap yang tidak bias sepanjang audit, sedangkan independensi dalam penampilan (independent in appearence) adalah hasil interprestasi lain atas independen ini. Seperti yang dikatakan oleh Agoes (2013, p146) bahwa independensi mencerminkan sikap tidak memihak serta tidak dibawah pengaruh atau tekanan pihak tertentu dalam mengambil keputusan dan tindakan.

Menurut Nur Barizah, dkk (2005) menyatakan bahwa terdapat paling sedikit enam faktor yang telah diuji mengenai persepsi terhadap independensi auditor: ukuran kantor akuntan publik, tingkat persaingan didalam pasar jasa audit, lamanya kantor akuntan publik memberikan pelayanan terhadap klien, besarnya biaya audit yang diterima oleh KAP, penyediaan jasa konsultan manajemen oleh KAP terhadap klien, dan keberadaan komite audit. Demikian yang dikemukakan oleh Veronica Sylvia, dkk (2011) menyatakakan bahwa jangka waktu audit yang terlalu lama menurunkan kualitas audit, tetapi terdapat temuan juga bahwa jika dilakukan rotasi audit akan menurunkan kualitas audit. Hal senada dikemukakan oleh Shafie et al. (2009) menyatakan jika klien tidak pernah mengganti auditor sejak terdaftar di Bursa Malaysia, ada kecenderungan untuk mengeluarkan pendapat bersih meskipun klien menderita masalah keuangan yang jelas.

Independensi akuntan publik adalah sebagai probabilitas gabungan untuk mendeteksi dan melaporkan kesalahan (Geiger and Rama, 2003). Selanjutnya Menurut Davis dan Hollie (2008) pengungkapan non audit fee dapat mengurangi keakuratan persepsi investor mengenai independensi akuntan publik, dan tingkat non audit fee yang sebanding dengan total audit fee memiliki dampak yang bervariasi terhadap persepsi investor tentang independensi akuntan publik dan perilaku pasar. Auditor memiliki mutlak sikap yang perlu dipertahankan, yaitu independensi. Sikap seperti membuat auditor dalam jalur yang 
benar dalam melakukan praktek mereka dan mempertahankan sikap sebagai kelompok yang mengusung kepercayaan rakyat untuk meningkatkan kredibilitas laporan keuangan yang dihasilkan oleh perusahaan (Susanti, 2013).

Kompetensi. Menurut Cheng, et al (2002) menyatakan kompetensi auditor adalah seseorang yang memiliki knowledge ( pendidikan, keahlian dan pengalaman) dan sikap serta prilaku etis dalam bekerja, sehingga dengan kompetensi yang dimiliki seseorang mampu menunjukan suatu perestasi. Kompetensi dalam pengauditan merupakan pengetahuan, keahlian dan pengalaman yang dibutuhkan auditor untuk dapat melakukan audit secara objektif, cermat dan seksama (Kharismatuti, dkk 2012).Demiikan yang dikemukakan oleh Deeprose (2006) menyatakan bahwa seorang yang kompeten akan lebih mudah dalam melaksanakan pekerjaannya dibanding orang yang tidak kompeten. Pengetahuain yang dimiliki oleh seorang auditor akan meningkatkan kualitas audit (Hay dan Davis, 2002). Selanjutnya Samelson et al (2006) menyatakan bahwa keahlian seorang auditor akan berpengaruh terhadap kualitas audit yang dihasilkan. Hal ini dikarenakan semakin sering mengikuti pelatihan, seminar dan semakin banyak sertifikat yang dimiliki diharapkan auditor akan semakin mampu melaksanakan tugasnya demikian menurut Raiyani dan Saputra (2014) serta pengalaman khusus dalam mendeteksi kesalahan dapat meningkatkan kemungkinan akuntan publik memberikan penjelasan yang benar dalam suatu prosedur analitis (Ed O’Donnell, 2002:66). Pengalaman audit adalah pengalaman auditor dalam melakukan audit laporan keuangan baik dari segi lamanya waktu maupun banyaknya penugasan yang pernah ditangani (Ida Suraida, 2005). Demikian menurut Mayangsari (2003) auditor yang berpengalaman memiliki keunggulan dalam hal mendeteksi kesalahan, memahami kesalahan secara akurat dan mencari penyebab kesalahan. Sehingga dalam hal ini menurut Alim, dkk (2007) dimana kompetensi didefinisikan sebagai aspek-aspek pribadi dari seorang pekerja yang memungkinkan mencapai kinerja yang superior. Akuntan mempunyai kewajiban untuk menjaga standar prilaku etis tertinggi mereka kepada organisasi dimana akuntan mempunyai tanggung jawab menjaga kompeten dan untuk menjaga integritas dan obyektivitas mereka .

Profesionalisme Auditor. Menurut Agoes (2013: 122) menyatakan profesionalisme yang memayungi profesi tersebut adalah semangat, paradigma, spirit, tingkah laku, ideologi, pemikiran gairah untuk terus menerus secara dewasa (mature), secara intelek meningkatkan kualitas profesi mereka. Sebagai profesional, auditor tidak boleh bertindak ceroboh atau dengan niat buruk, tetapi mereka tidak juga diharapkan selalu sempurna (Arens, et al., 2013: 43). Sedangkan menurut Messier, et al. (2014, p53) kecermatan profesional berarti bahwa auditor merencanakan dan melakukan tugasnya dengan keterampilan dan kepedulian yang secara umum diharapkan dari akuntan profesional. Sementara menurut Sinaga dan Isgiyarta (2012) sebagai profesional, akuntan publik mengakui tanggung jawabnya terhadap masyarakat, terhadap klien dan terhadap rekan seprofesi termasuk untuk berperilaku yang terhormat, sekalipun ini merupakan pengorbanan pribadi. Standar Profesi Akuntan Publik (2011) seksi 150 menyatakan prinsip perilaku profesional mewajibkan setiap praktisi untuk memenuhi setiap ketentuan hukum dan peraturan yang berlaku, serta menghindari setiap tindakan yang dapat mendiskreditkan profesi. Menurut Herawaty (2009), ada lima dimensi mengenai 
profesionalisme, yaitu (1) Pengabdian pada profesi, (2) Kewajiban sosial, (3) Kemandirian, (4) Keyakinan terhadap profesi dan (5) Hubungan dengan sesama profesi.

Pertimbangan Materialitas. Gambaran mengenai definisi materialitas dalam penelitian ini berdasarkan dari beberapa pendapat antara lain:Tuanakotta (2014, p159) menyatakan bahwa materialitas mengukur apa yang dianggap signifikan oleh pemakai laporan keuangan dalam membuat keputusan ekonomis. Hal - hal yang dianggap signifikan ini biasanya menyangkut salah saji dalam laporan keuangan. Ketika salah saji signifikan mampu mengubah pengambilan keputusan seseorang, maka salah saji material telah terjadi. Sementara menurut Hayes dan Gortemaker (2014: 202), materialitas adalah konsep yang digunakan untuk mendesain audit sehingga auditor dapat memperoleh keyakinan memadai bahwa terdapat salah saji material baik dari ukurannya maupun sifatnya.

Materialitas adalah besarnya nilai yang dihilangkan atau salah saji informasi akuntansi, yang dilihat dari keadaan yang melingkupi, dapat mengakibatkan perubahan atau pengaruh terhadap pertimbangan orang yang meletakan kepercayaan terhadap informasi tersebut karena adanya penghilangan atau salah saji itu. Definisi materialitas mengharuskan auditor untuk mempertimbangkan baik keadaan yang berkaitan dengan entitas dan kebutuhan informasi pihak yang akan meletakan kepercayaan atas laporan keuangan auditan (Mulyadi, 2013;158). Demikian menurut Suryanita Weningtyas, et al (2006) menyatakan bahawa saat auditor menetapkan materialitas yang melekat pada suatu prosedur audit rendah maka adanya kecenderungan bagi auditor untuk mengabaikan prosedur audit, dengan asumsi jika ditemukan salah saji dari pelaksanaan suatu prosedur audit, nilainya tidak material sehingga tidak berpengaruh pada opini audit.

Menurut Faux (2012), pengungkapan informasi material, salah satu masalah yang paling signifikan dalam akuntansi, adalah didasarkan pada gagasan bahwa materialitas merupakan pusat paradigma keputusan kegunaan dalam akuntansi. Gagasan materialitas mengandaikan kemampuan akuntan untuk menentukan apakah penilaian pada materialitas mempengaruhi keputusan pengguna. Sedangkan menurut Kieso,et al. (2011, p57) juga mengatakan materialitas ditentukan dengan seberapa besar ukuran dan dampaknya terhadap para pengambil keputusan. Jumlah ini harus signifikan jika dibandingkan dengan pendapatan, beban, aset, kewajiban, dan laba bersih dari perusahaan tersebut yang dilaporkan sesuai dengan standar yang berlaku umum. Jika jumlahnya terlalu kecil saat dibandingkan, maka bisa dikatakan bahwa akun tersebut tidaklah material sehingga tidak memerlukan pengungkapan perusahaan.

Paradigma Penelitian dan Perumusan Hipotesis. Berdasarkan uraian diatas, maka inti dari penelitian ini adalah bagaimana pengaruh independensi, kompetensi, dan profesionalisme auditor terhadap pertimbangan tingkat materialitas dalam pemeriksaan laporan keuangan. Hal ini didukung dengan penelitian terdahulu yang menyatakan bahwa semakin tinggi independensi, kompetensi dan profesionalisme seorang auditor maka semakin baik pula pertimbangan materialitasnya. Maka penulis dapat merumuskan hipotesis penelitian :

$\mathrm{H}_{1}$ : Independensi berpengaruh positif terhadap pertimbangan tingkat materialitas dalam pemeriksaan laporan keuangan.

$\mathrm{H}_{2}$ : Kompetensi berpengaruh positif terhadap pertimbangan tingkat materialitas dalam pemeriksaan laporan keuangan. 
$\mathrm{H}_{3}$ : Profesionalisme auditor berpengaruh positif terhadap pertimbangan tingkat materialitas dalam pemeriksaan laporan keuangan.

$\mathrm{H}_{4}$ : Independensi, Kompetensi, dan Profesionalisme auditor secara bersama-sama berpengaruh signifikan terhadap pertimbangan tingkat materialitas dalam pemeriksaan laporan keuangan.

Hubungan akan hal ini digambarkan dalam paradigma penelitian (Gambar 1)

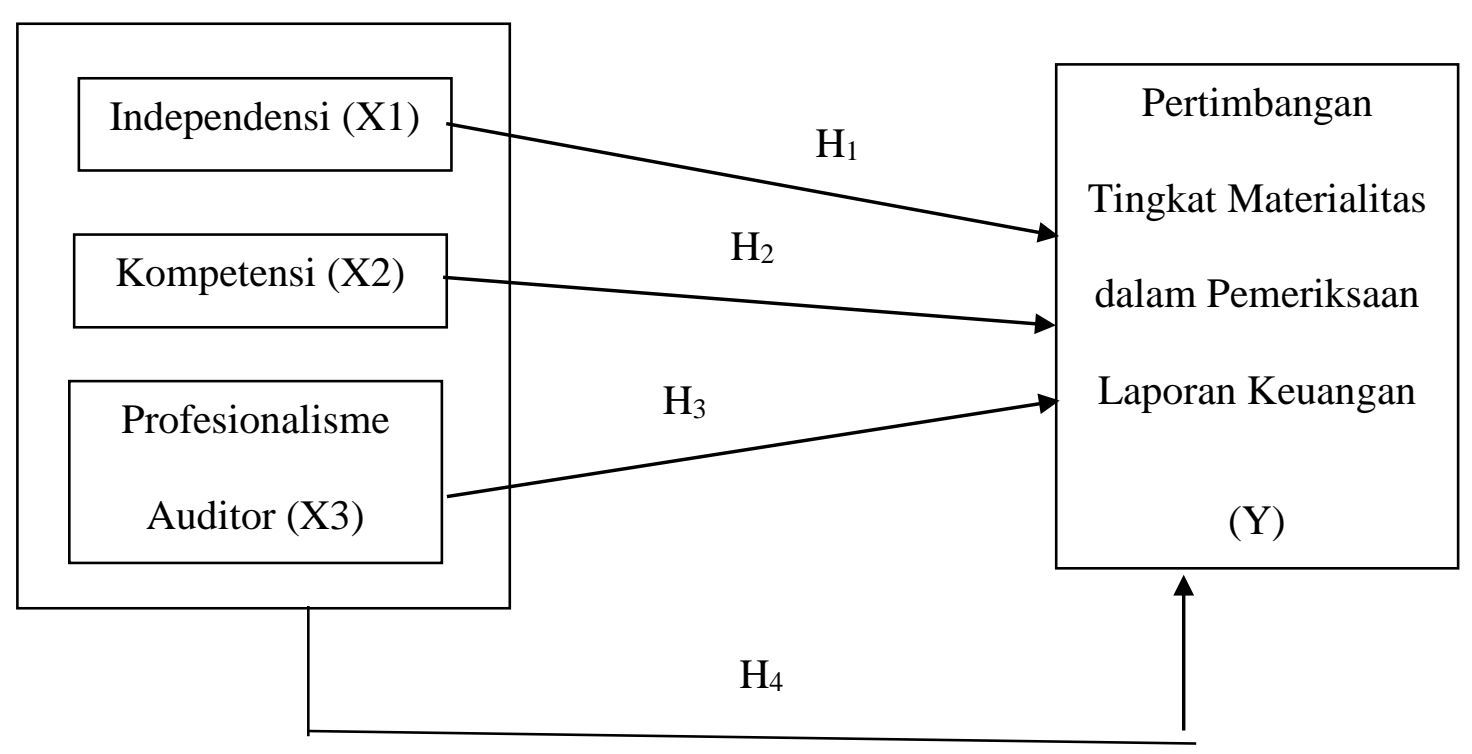

Gambar 1. Rerangka Penelitian

\section{METODE}

Subjek penelitian dalam penelitian ini adalah para auditor yang bekerja pada Kantor Akuntan Publik di wilayah Jakarta Pusat dan Jakarta Selatan. Dalam penelitian ini yang menjadi objek penelitian terbagi dalam dua variabel. Variabel indepeden penelitian ini berupa independensi, kompetensi, dan profesionalisme dari seorang auditor eksternal. Variabel dependen penelitian ini berupa pertimbangan tingkat materialitas dalam pemeriksaan laporan keuangan.

Penelitian ini merupakan penelitian kuantitatif. Sedangkan jenis penelitian yang digunakan dalam penelitian ini adalah penelitian kausal-komparatif yang termasuk dalam bagian penelitian asosiatif atau hubungan yang bertujuan untuk mengetahui hubungan antar dua variabel atau lebih serta mengetahui pengaruhnya (Sujarweni, 2014: 11).

Populasi dan Sampel Penelitian. Peneliti menggunakan populasi dari kantor akuntan publik yang berada di DKI Jakarta dengan konsentrasi wilayah Jakarta Pusat dan Jakarta Selatan, Pada tahun 2015 terdapat 246 KAP yang terletak di DKI Jakarta terdiri dari 64 KAP di Jakarta Pusat dan 94 KAP di Jakarta Selatan yang terdaftar dalam Institut Akuntan Publik Indonesia (IAPI).

Penelitian menggunakan teknik pengambilan sampel probability sampling dengan metode pengambilan sampelnya menggunakan simple random sampling. Hal ini berarti 
setiap KAP diberikan kesempatan yang sama dalam berpartisipasi mengisi kuesioner yang diajukan peneliti dan pengambilan sampel dilakukan secara acak. Dalam penyebaran yang dilakukan, berhasil dikumpulkan 33 sampel KAP yang bersedia menjadi responden yang terdiri dari 96 responden yang dapat diolah datanya.

Metode Analisis. Data yang digunakan adalah data primer yang berasal dari lapangan dengan menyebarkan kuesioner yang diberi skala likert 1-7 dengan hasil olahan menggunakana skala interval (Zikmud, et al 2013, p297). Analisis dan pengolahan data yang dilakukan dengan menggunakan aplikasi komputerisasi komputer SPSS 22.0.

Teknik uji validitas yang digunakan dalam penelitian ini adalah korelasi Pearson (Pearson Correlation) yaitu pengujian signifikansi dilakukan dengan kriteria nilai positif nilai sig 2-tail dari skor total $<0,05$ dan nilai $\mathrm{r}$ hitung $>$ dari $\mathrm{r}$ tabel 0.2028 dimana degree of fredom (df) = 96-3-1 = 92 maka item dapat dinyatakan valid (Priyatno, 2014, p51). Sementara untuk uji reliabilitas peneliti menggunakan metode Cronbach's Alphadengan batasan 0,6adalah kurang baik, sedangkan 0,7 dapat diterima dan diatas 0,8 adalah baik (Sekaran dalam Priyatno, 2014, p64). Sementara uji asumsi klasik dibagi menjadi normalitas residual dengan grafik p-p plot, multikolinieritasdengan melihat nilai tolerance dan variance inflation factor (VIF) pada model regresi, autokorelasi dengan menggunakan uji Durbin Watson (DW Test), dan heteroskedastisitas dengan metode korelasi Spearman's rho dan grafik scatterplots (Priyatno, 2014).

Priyatno (2014:156), dalam pengujian hipotesis koefisien determinasi dilihat dari besarnya nilai Adjusted $\mathrm{R}$ Square untuk menunjukan sumbangan pengaruh variabel independen terhadap variabel dependen. Sementara uji hipotesis yang dilakukan terdiri dari uji t untuk uji hipotesis partial dan uji F untuk uji hipotesis simultan.

\section{HASIL DAN PEMBAHASAN}

Penelitian ini menggunakan data primer yang diperoleh dari penyebaran kuesioner Pengaruh Independensi, Kompetensi, dan Profesionalisme Auditor terhadap pertimbangan tingkat materialitas dalam pemeriksaan laporan keuangan kepada auditor pada Kantor Akuntan Publik yang berada di wilayah Jakarta Pusat dan Jakarta Selatan sesuai yang tercatat dalam direktori IAPI. Proses penyebaran kuesioner dilaksanakan pada masa sibuk auditor yakni bulan Oktober - November 2015, sehingga respons rate responden memiliki probabilitas rendah. Oleh karena itu jumlah keseluruhan responden adalah 96 orang dengan KAP yang menjadi sampel sebanyak 33 Kantor Akuntan Publik dari 121 kuesioner yang disebar pada 42 kantor akuntan publik yang terdapat di Jakarta Pusat dan Jakarta Selatan.

Responden terdiri dari 52 orang berjenis kelamin laki-laki dan 44 orang berjenis kelamin perempuan dengan 93 orang lulusan S1 dan 3 orang lulusan S2. Adanya perbedaan jumlah auditor laki-laki dan perempuan dikarenakan adanya konsep kultural yang berupaya membuat pembedaan (distinction) dalam hal peran, perilaku, mentalitas, dan karakteristik emosional laki-laki dan perempuan yang berkembang dalam masyarakat (Putra, 2012).Responden dengan jabatan senior auditor terdiri dari 83 orang, sedangkan 10 orang supervisor dan 3 orang manajer audit. Sementara auditor dengan pengalaman 1-3 tahun yang menjadi responden sebanyak 45 orang dan 26 orang auditor dengan pengalaman 3,5-6 tahun, sementara auditor dengan pengalaman 6,5 - 10 tahun dan diatas 10 tahun masing - masing berjumlah 12 dan 13 orang. 
Hasil Analisis Data. Model regresi linier dikatakan sebagai model yang baik harus terpenuhinya asumsi klasik agar diperoleh model regresi dengan estimasi yang tidak bias dan pengujian dapat dipercaya. Pertama, Uji normalitas bertujuan untuk menguji apakah model regresi memenuhi asumsi normalitas yaitu variabel dependen dan independen keduanya berdistribusi normal atau tidak.

Angka Tolerance dari variabel bebas independensi, kompetensi, dan profesionalisme auditor mempunyai nilai lebih dari 0,10 yakni 0,515;0,474; dan 0,582 dan nilai Variance Inflation Factor (VIF) tidak lebih atau kurang dari 10 yakni 1,941; 2,111 ; dan 1,717. Dengan demikian dapat disimpulkan bahwa dalam model regresi tidak terjadi multikolinieritas antar variabel bebas.

Sedangkan untuk uji autokorelasi dapat terlihat dari nilai Durbin Watson (DW) 2,217 yang didapat dari hasil uji autokorelasi. Nilai ini lah yang akan dibandingkan dengan DU dan 4-DU untuk melihat terjadi atau tidaknya autokorelasi. Nilai DU dan DL sendiri dapat diperoleh dari tabel statistik Durbin Watson. Dengan tingkat signifikansi 5\%, dan banyaknya n adalah 96, serta k (banyaknya variabel independen) sebanyak 3 variabel, maka didapatlah nilai DU sebesar 1,7326 dan nilai 4-DU (4 - 1,7326) sebesar 2,2674. Maka uji durbin-watson menghasilkan DU=1,7326 < DW= 2,217 < 4-DU= 2,2674 yang artinya tidak terjadi autokorelasi. Sementara untuk uji heteroskedastisitas, dapat dilihat dengan metode korelasi Spearman's rhoyang memberi hasil output bahwa korelasi antara variabel independen (independensi, kompetensi dan profesionalisme auditor) dengan Unstandardized Residual memiliki nilai signifikansi (sig 2-tailed) lebih dari 0,05 yakni 0,735 ; 0,548 ; 0,735. Karena signifikansi lebih besar dari 0,05 dapat disimpulkan bahwa tidak terjadi masalah heteroskedastisitas dan jika dengan menggunakan grafik scatterplots.

Selanjutnya uji koefisien determinasi bertujuan untuk mengukur seberapa jauh kemampuan model dapat menjelaskan variasi variabel dependen. adapun hasil Uji Koefisien Determinasi (R2) sebagai berikut:

Tabel 1. Hasil Uji koefisien Determinasi

\begin{tabular}{lrrrr}
\multicolumn{5}{c}{ Model Summary $^{\mathbf{b}}$} \\
\hline Model & \multicolumn{1}{c}{ R } & R Square & Adjusted R Square & Std. Error of the Estimate \\
\hline 1 & $.839^{\mathrm{a}}$ & .705 & .695 & 2.589 \\
\hline
\end{tabular}

a. Predictors: (Constant), Profesionalisme Auditor, Independensi, Kompetensi

b. Dependent Variable: Pertimbangan Materialitas

Adapun hasil uji regresi linier berganda dan hasil uji t partial seperti terlihat pada Tabel 2.

Berdasarkan Tabel 2, nilai koefisien determinasi yang sudah disesuaikan (Adjusted $\mathrm{R}$ Square) adalah 0,695. Hal ini berarti 69,5\% variasi dari pertimbangan materialitas dapat dijelaskan oleh variasi variabel independen yakni Independensi, Kompetensi, dan Profesionalisme auditor yang terdapat dalam penelitian ini. Sedangkan sisanya sebesar $30,5 \%$ dijelaskan atau dipengaruhi oleh variabel lain yang tidak ada dalam penelitian. Kemudian uji regresi berganda dan uji hipotesis. Analisis regresi linier berganda digunakan untuk mengetahui pengaruh antara variabel independen terhadap variabel dependen. 
Tabel 2. Hasil Uji Regresi Linier Berganda dan Uji Hipotesis

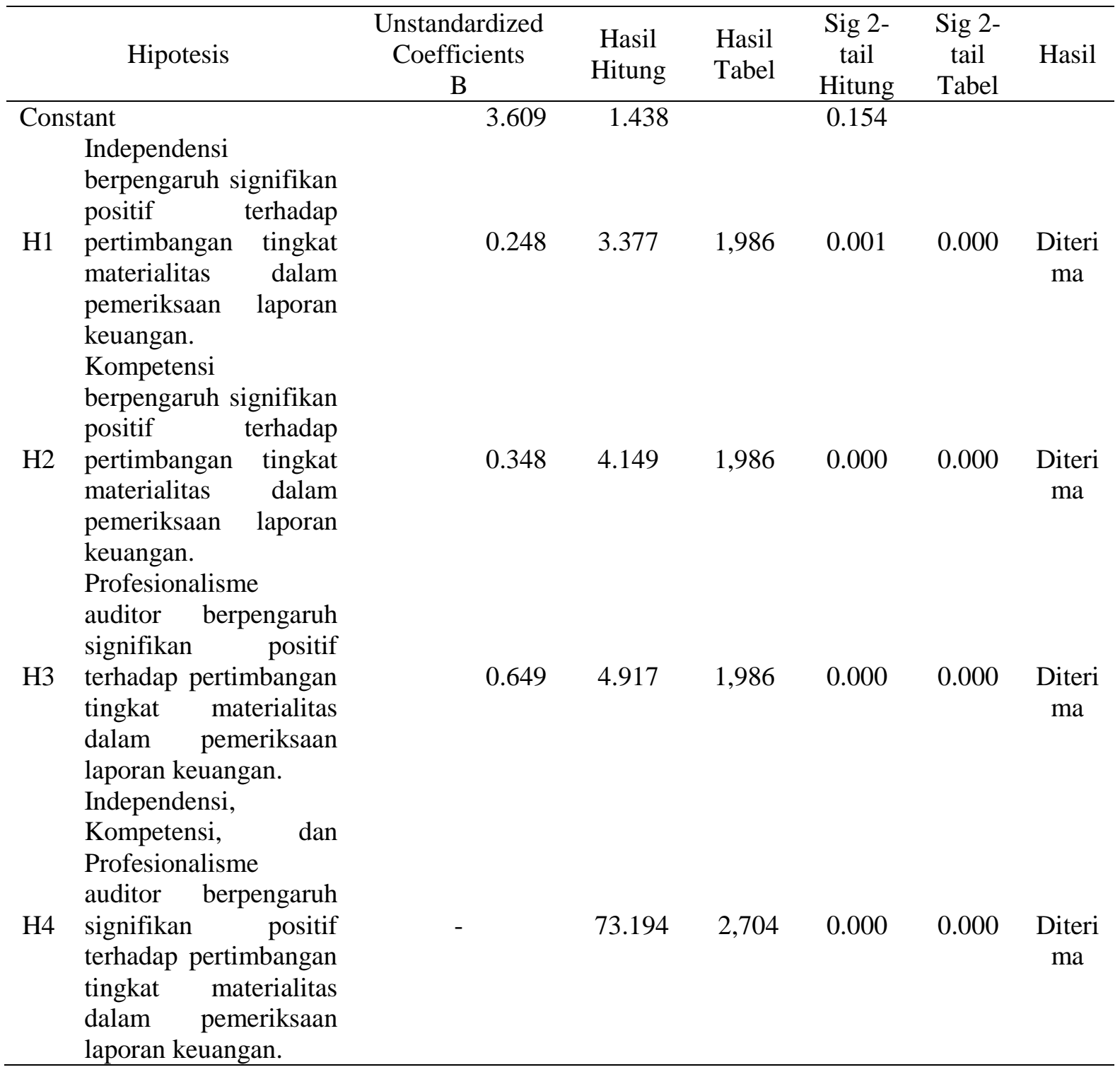

Berdasarkan Tabel 2 hasil yang telah diperoleh dari koefisien regresi di atas, maka dapat dibuat suatu persamaan regresi sebagai berikut:

$$
\begin{aligned}
& \mathrm{Y}=\alpha+\beta 1 \mathrm{X} 1+\beta 2 \mathrm{X} 2+\beta 3 \mathrm{X} 3+\mathrm{e} \\
& \mathrm{Y}=3,609+0,248 \mathrm{X} 1+0,348 \mathrm{X} 2+0,649 \mathrm{X} 3
\end{aligned}
$$

Koefisien regresi pada Tabel 2 dapat diartikan bahwa variabel independensi, kompetensi, dan profesionalisme auditor berpengaruh positif terhadap pertimbangan materialitas. Hal ini menunjukkan bahwa ketika independensi, kompetensi, dan profesionalisme auditor mengalami peningkatan maka pertimbangan materialitas juga akan mengalami peningkatan.

Berdasarkan Tabel 3, dapat dilihat nilai uji t partial. Uji t menunjukkan seberapa jauh pengaruh satu variabel penjelas atau independen dalam penelitian ini adalah independensi, 
kompetensi, dan profesionalisme auditor secara individual dalam menerangkan variasi variabel dependen pertimbangan materialitas dan digunakan untuk mengetahui ada atau tidaknya pengaruh masing-masing variabel independen secara individual terhadap variabel dependen yang diuji pada tingkat signifikansi 0,05.

Hasil output analisis terlihat bahwa nilai t hitung dari masing-masing variabel yaitu variabel independensi sebesar 3,377 dengan signifikansi 0,001. Variabel kompetensi dengan nilai $t$ hitung sebesar 4,149 dengan signifikansi 0,000, dan variabel profesionalisme auditor dengan nilai t hitung sebesar 4,917 dengan signifikansi 0,000. Adapun nilai t tabel 1,986 dengan degree of fredom (df) $=96-3-1=92$ dan nilai signifikansi sig 2-tail 0,05. Hal ini berarti hipotesis Ho ditolak, dengan kata lain independensi, kompetensi, dan profesionalisme auditor berpengaruh terhadap pertimbangan materialitas dalam pemeriksaan laporan keuangan.

Uji hipotesis yang terakhir adalah uji F, dimana uji statistik ini digunakan untuk mengetahui apakah secara simultan atau bersama-sama variabel independen mempengaruhi variabel dependen. Adapun hasil output uji F simultan sebagai berikut:

Berdasarkan Tabel 2,dapat dilihat hasil uji F memberi nilai Fhitung sebesar 73,194 sedangkan $\mathrm{F}$ tabel sebesar 2,704 dengan degree of fredom (df) $=96-3-1=92$ dan nilai signifikansi sig 2-tail 0,05. Sementara tingkat signifikansinya $0,000<0,05$. Karena nilai $\mathrm{F}$ hitung $>$ F tabel dan tingkat signifikansi $<0,05$ maka Ho ditolak, sehingga independensi, kompetensi, dan profesionalisme auditor berpengaruh secara bersama-sama terhadap pertimbangan materialitas dalam pemeriksaan laporan keuangan.

Interprestasi Data. Dalam menentukan opini bagi suatu laporan keuangan, auditor membutuhkan penilaian salah saji yang terjadi. Salah saji yang mempengaruhi adalah salah saji material yang nilai dan sifatnya dapat mempengaruhi pengambilan keputusan. Oleh karena itu pertimbangan tingkat materialitas sangat dibutuhkan dalam melakukan audit. Dalam penelitian ini didapat nilai koefisien determinasi (R2) sebesar 69,5\%. Sehingga dapat dikatakan bahwa independensi, kompetensi, dan profesionalisme auditor mempengaruhi pertimbangan materialitas sebesar 69,5\%, sementara sisanya dijelaskan oleh model dan faktor lain diluar penelitian ini.

\section{Pengaruh Independensi Auditor $\left(\mathrm{X}_{1}\right)$ terhadap Pertimbangan Tingkat Materialitas} (Y). Berdasarkan hasil analisis data penelitian yang telah penulis uraikan diatas, terdapat pengaruh independensi terhadap pertimbangan tingkat materialitas secara parsial yang dibuktikan dengan nilai t hitung variabel independensi sebesar 3,377 dengan signifikansi 0,001 yang artinya t hitung $=3,377>\mathrm{t}$ tabel 1,986 dan signifikansi 0,001 $<0,050$. Sementara berdasarkan hasil analisis uji regresi linier berganda, variabel independensi menyumbang pengaruh sebesar $24,8 \%$ terhadap pertimbangan tingkat materialitas dimana bila variabel lain bernilai konstan (0) maka tingkat pertimbangan materialitas dalam pemeriksaan laporan keuangan akan meningkat sebanyak 24,8\%.

Hasil ini menunjukan bahwa, auditor yang memegang teguh independensi akan menghasilkan pertimbangan materialitas yang baik karena pertimbangan auditor tersebut tidak akan mudah terpengaruh dalam menetapkan tingkat materialitas laporan keuangan suatu entitas walaupun terdapat konflik kepentingan yang belum terselesaikan terkait dengan entitas tersebut. Auditor yang independen akan tetap fokus ketika melakukan pengumpulan dan pengevaluasian bukti sehingga temuan audit sesuai dengan kondisi 
lapangan yang dapat menunjang keputusan auditor dalam menentukan pertimbangan tingkat materialitas.

Hal ini sejalan dengan penelitian Kinanti (2013) yang menyatakan independensi berpengaruh signifikan dan berkorelasi positif terhadap pertimbangan materialitas berdasarkan hasil uji regresi linier berganda yang dilakukan. Pengaruh positif artinya semakin tinggi independensi yang dimiliki seorang auditor, maka semakin baik pula pertimbangan tingkat materialitas yang dihasilkan auditor dalam pemeriksaan laporan keuangan.

Berdasarkan hasil tersebut dapat terlihat semakin tinggi independensi seorang auditor, maka pertimbangan tingkat materialitasnya semakin baik. Hal ini harus didukung oleh Kantor Akuntan Publik untuk memberikan motivasi dalam menjaga independensi selama penugasan. Bila pertimbangan materialitas sudah baik maka opini yang dihasilkan juga pasti akan baik dan tidak menyesatkan para pengguna laporan keuangan.

\section{Pengaruh Kompetensi Auditor $\left(\mathrm{X}_{2}\right)$ terhadap Pertimbangan Tingkat Materialitas (Y)}

Berdasarkan hasil analisis data penelitian yang telah penulis uraikan diatas, terdapat pengaruh kompetensi terhadap pertimbangan tingkat materialitas secara parsial yang dibuktikan dengan nilai t hitung variabel kompetensi sebesar 4,149 dengan signifikansi 0,000, yang artinya t hitung $=4,149>\mathrm{t}$ tabel 1,986 dan signifikansi 0,000 $<0,050$. Sementara berdasarkan hasil analisis uji regresi linier berganda, variabel kompetensi menyumbang pengaruh sebesar 34,8\% terhadap pertimbangan tingkat materialitas dimana bila variabel lain bernilai konstan (0) maka tingkat pertimbangan materialitas dalam pemeriksaan laporan keuangan akan meningkat sebanyak 34,8\%.

Hasil ini menunjukan bahwa kompetensi sangat berperan penting dalam penetapan tingkat materialitas bagi seorang auditor. Kompetensi seorang auditor dapat diperoleh dengan pendidikan dan pelatihan teknis yang cukup dalam praktik akunansi dan teknik auditing. Jika seorang auditor memiliki kompetensi yang cukup, baik pengetahuan maupun pengalamannya, maka auditor tersebut akan dengan mudah melakukan tugas - tugas auditnya termasuk menetapkan tingkat materialitas. Kecil kemungkinan auditor yang berkompeten salah menetapkan tingkat materialitas, karena auditor yang berkompeten pasti memikirkan dengan segala aspek yang ada terkait tingkat materialitas suatu entitas.

Hal ini sejalan dengan penelitian Kinanti (2013) yang menyatakan kompetensi berpengaruh signifikan positif terhadap pertimbangan materialitas berdasarkan hasil uji regresi linier berganda yang dilakukan. Pengaruh positif artinya semakin tinggi tingkat kompetensi yang dimiliki seorang auditor, maka semakin tinggi pula pertimbangan tingkat materialitas dalam pemeriksaan laporan keuangan.

Berdasarkan hasil tersebut dapat terlihat bahwa semakin tinggi kompetensi yang dimiliki oleh seorang auditor, maka auditor tersebut memiliki kemampuan lebih dalam melihat pola dan kecenderungan kesalahan yang mungkin muncul dalam laporan keuangan. Untuk meningkatkan kompetensi tersebut, auditor harus didukung Kantor Akuntan Publik untuk memberikan pelatihan, training, atau seminar guna meningkatkan pengetahuan auditor itu sendiri.

Pengaruh Profesionalisme Auditor $\left(\mathrm{X}_{3}\right)$ terhadap Pertimbangan Tingkat Materialitas (Y). Berdasarkan hasil analisis data penelitian yang telah penulis uraikan diatas, terdapat pengaruh profesionalisme auditor terhadap pertimbangan tingkat 
materialitas secara parsial yang dibuktikan dengan nilai t hitung variabel profesionalisme auditor sebesar 4,917 dengan signifikansi 0,000, yang artinya thitung $=4,917>\mathrm{t}$ tabel 1,986 dan signifikansi $0,000<0,050$. Sementara berdasarkan hasil analisis uji regresi linier berganda, variabel profesionalisme auditor menyumbang pengaruh sebesar $64,9 \%$ terhadap pertimbangan tingkat materialitas dimana bila variabel lain bernilai konstan (0) maka tingkat pertimbangan materialitas dalam pemeriksaan laporan keuangan akan meningkat sebanyak $64,9 \%$.

Seorang auditor profesional pasti akan bertanggung jawab melaksanakan tugasnya dengan tekun dan seksama. Hal ini juga diterapkan dalam penetapan tingkat materialitas, auditor yang profesional pasti merencanakan dan melakukan tugasnya dengan keterampilan dan kepedulian yang secara umum diharapkan dari akuntan profesional. Sikap profesionalisme mendukung penetapan tingkat materialitas karena dalam penetapan tingkat materialitas laporan keuangan entitas dibutuhkan pemikiran yang menyeluruh akan entitas tersebut yang harus dilakukan dengan tekun dan seksama.

Hal ini sejalan dengan penelitian Herawaty (2009) dan Minanda (2013) yang menyatakan profesionalisme auditor berpengaruh signifikan dan berkorelasi positif terhadap pertimbangan materialitas berdasarkan hasil uji regresi linier berganda yang dilakukan. Pengaruh positif artinya semakin tinggi tingkat profesionalisme yang dimiliki seorang auditor, maka semakin tinggi pula pertimbangan tingkat materialitas dalam pemeriksaan laporan keuangan. Berdasarkan hasil tersebut dapat terlihat bahwa seorang auditor yang profesional seharusnya bertindak secara hati-hati dan selalu cermat dan bertanggungjawab terhadap tugasnya. Tanggungjawab tersebut dapat dilakukan dengan mempertimbangkan tingkat materialitas dengan penuh kehati - hatian. Pertimbangan tersebut harus dilakukan dengan memperluas pemahamannya dan dengan tetap meningkatkan sikap skeptisisme.

Pengaruh Secara Simultan Independensi Auditor $\left(\mathrm{X}_{1}\right)$, Kompetensi Auditor $\left(\mathrm{X}_{2}\right)$, dan Profesionalisme Auditor $\left(\mathrm{X}_{3}\right)$ terhadap Pertimbangan Tingkat Materialitas (Y). Berdasarkan hasil analisis data penelitian melalui pengujian hipotesis yang telah penulis uraikan diatas, terdapat pengaruh independensi, kompetensi, dan profesionalisme auditor terhadap pertimbangan tingkat materialitas secara simultan yang dibuktikan dengan nilai $\mathrm{F}$ hitung sebesar 73,194 sedangkan $\mathrm{F}$ tabel sebesar 2,704 dengan tingkat signifikansi 0,000 < 0,05 sehingga nilai $\mathrm{F}$ hitung $>\mathrm{F}$ tabel dan tingkat signifikansi $<0,05$.

Dari hasil penelitian yang ada didapatkan hasil bahwa variabel kompetensi dan profesionalisme seorang auditor memiliki tingkat signifikan 0,000 akan tetapi jika dilihat dari persamaan regresi yang ada, nilai profesionalisme auditor sebesar 0,649 lebih dari kompetensi yang hanya 0,348 dan variabel independensi menempati posisi paling akhir hanya dengan 0,248 .

Hal ini menunjukan bahwa seorang auditor yang memiliki sikap professional akan menempatkan dirinya dalam posisi yang berhati - hati dan cermat serta bertanggungjawab terhadap tugasnya. Sikap professional dari seorang auditor saja tidak cukup untuk menentukan tingkat materialitas dalam suatu laporan keuangan. Sikap profesionalisme haruslah didukung oleh kompetensi dari dalam diri auditor itu sendiri agar auditor dapat melakukan yang terbaik bagi pekerjaannya mulai dari perencanaan sampai dengan pengambilan keputusan pemberian opini yang didasarkan pada salah saji material. Kompetensi membuat auditor menggunakan pengetahuannya dalam menentukan tingkat material yang dianggap menjadi salah satu proses yang amat penting karena hal ini 
berkaitan dengan opini yang dihasilkan bagi kepentingan publik. Seorang profesional pasti harus memutuskan dengan akal sehat dan pengetahuan luas tanpa adanya intervensi dari pihak manapun. Oleh karena itu, seorang auditor yang profesional dengan tingkat kompetensi tinggi belum dikatakan baik pertimbangan materialitasnya jika terdapat intervensi dari pihak lain. Hal ini menyebabkan independensi sebagai faktor pelengkap yang harus dimiliki seorang auditor dalam menentukan tingkat materialitas laporan keuangan klien, karena mempertahankan etika atau integritas jauh lebih sulit dikarenakan banyak faktor yang mempengaruhi.

Berdasarkan hasil analisis tersebut memberikan implikasi bahwa dalam mempertimbangkan tingkat materialitas yang baik memerlukan independensi, kompetensi dan profesionalisme auditor yang baik pula.

\section{PENUTUP}

Simpulan. Berdasarkan hasil analisis, maka pada penelitian ini dapat disimpulkan:(1) Independensi berpengaruh positif terhadap pertimbangan tingkat materialitas dalam pemeriksaan laporan keuangan. Hal ini berarti semakin tinggi independensi auditor, maka semakin tinggi pula petimbangan materialitas yang diambil; (2) Kompetensi berpengaruh positif terhadap pertimbangan tingkat materialitas dalam pemeriksaan laporan keuangan. Hal ini berarti semakin baik kompetensi auditor, maka semakin baik pula petimbangan materialitas yang diambil; (3) Profesionalisme auditor berpengaruh positif terhadap pertimbangan tingkat materialitas dalam pemeriksaan laporan keuangan. Hal ini berarti semakin tinggi profesionalisme auditor, maka semakin tinggi pula pertimbangan materialitas yang diambil; (4) Independensi, Kompetensi, dan Profesionalisme auditor berpengaruh terhadap pertimbangan tingkat materialitas dalam pemeriksaan laporan keuangan. Hal ini berarti variabel independen sangat berpengaruh secara simultan terhadap variabel dependen.

Saran. Adapun saran yang dapat diberikan guna perbaikan penelitian ini dikemudian hari dibagi menjadi saran operasional dan saran pengembangan ilmu. Saran operasional, bagi para auditor diharapkan mampu mempertahankan dan meningkatkan sikap independensi, kompetensi dan menjaga profesionalisme karena faktor tersebut diperlukan untuk meningkatkan pertimbangan auditor dalam menentukan tingkat materialitas dalam memutuskan pemeriksaan laporan keuangan. Sementara bagi KAP, diharapkan sebagai wadah bernaungnya para auditor dapat memberi motivasi agar para auditor menjaga sikap independensi dan profesionalismenya yang diimbangi dengan pelaksanaan seminar dan pelatihan bagi para calon akuntan publik. Bagi regulator IAI / IAPI, diharapkan sebagai organisasi yang mengeluarkan aturan tentang audit laporan keuangan mengeluarkan aturan yang pasti terkait penetapan tingkat materialitas sehingga para auditor memiliki pegangan pasti dalam mempertimbangkan tingkat materialitas laporan keuangan.

Saran pengembangan ilmu yang dapat diberikan adalah wilayah cakupan penelitian bukan hanya Jakarta Pusat dan Jakarta Selatan dengan responden yang lebih banyak sehingga lebih mencerminkan kondisi lapangan. Selain itu, dalam pengambilan sampel penelitian, diharapkan penelitian dapat mengembangkan sampel seluas mungkin bukan hanya auditor non big four tetapi dapat meluas ke auditor big four.Variabel independen dapat dikembangkan dengan variabel lain seperti skeptisisme profesional yang 
mencerminkan kehati - hatian seorang auditor, kualitas audit yang berpengaruh terhadap tingkat materialitas yang ditetapkan, serta etika profesi dari seorang auditor itu sendiri.

\section{DAFTAR RUJUKAN}

Adrian. A. (2013) Pengaruh Skeptisisme Profesional, Etika, Pengalaman, dan Keahlian Audit Terhadap Ketepatan Pemberian Opinioleh Auditor (Studi Empiris pada BPK RI Perwakilan Provinsi Riau). E-Jurnal Universitas Negeri Padang. Diunduh pada 10 Mei 2015 dari www.ejournal.unp.ac.id.

Alim, Hapsari, Purwanti. (2007) Pengaruh Kompetensi dan Independensi Terhadap kualitas Audit dengan Etika Auditor sebagai variabel moderat. Simposium Nasional Akuntansi X Makasar.

Agoes, S., \& Ardana, I.C. (2013) Etika Bisnis dan Profesi: Tantangan Membangun Manusia Seutuhnya. Edisi Revisi. Jakarta: Salemba Empat.

Agoes, Soekrisno. (2013) Auditing (Pemeriksaan Akuntan) oleh Kantor Akuntan Publik Edisi Ketiga; Jilid 1. Lembaga Penerbit Fakultas Ekonomi Universitas Indonesia, Jakarta.

Arens, A.A., Elder, R.J., Beasley, M.S., \& Jusuf, A.A. (2013) Jasa Audit dan Assurance: Pendekatan Terpadu (Adaptasi Indonesia). Buku 1. Jakarta: Salemba Empat.

Audsabumrungrat, J., \& Pornupatham, S. (2012) The Impact of Mechanical Guidance and Justification Requirement on Judgment of Auditors of Different Ranks in Materiality Determination.Global Conference on Business and Finance Proceedings, 7 (1): 302314). Thailand: Chulalongkorn University.

Bambang Soesatyo. (2011) Tiga Auditor BPK Tidak Bersertifikat CFE. Waspada Online (25 Desember 2011).

Cheng, Rita H, John H. Engstrom, Susan C Kattelus. (2002) Educating Government Financial Manager. University Collaboration Between Bussiness and Public Adminstration. The Journal of Government Financial Management. Alexandria, 51: $10-15$.

Davis, Shawn M and Hollie. (2008) The Impact of Nonaudit Service Fee Levels on Investor's Perception of Auditor Independensi Behavioral Research in Accounting. Sarosota, 20 (1): 14-31.

Deeprose, Donna. (2006) Smart Things To Know About Motivation. Dialih bahasakan oleh Soesanto B. Penerbit PT. Alex Media Komputindo. Jakarta.

Ed O’Donnell. (2002) Evidence of on Association between Error-Speciific Experience and Auditor Performance during Analytical Procedures. Behavior Research In Accounting. 14 (2): 178-190.

Ekawati, L.P. (2013) Pengaruh Profesionalisme, Pengalaman Kerja dan Tingkat Pendidikan Auditor, Terhadap Pertimbangan Tingkat Materialitas (Studi Empiris Pada Kantor Akuntan Publik di Wilayah Bali). Jurnal Ilmiah Akuntansi dan Humaniora.. 3 (1), Bali: Universitas Pendidikan Ganesha.

Faux. J. (2012) Environmental event materiality and decision making. Managerial Auditing Journal. 27 (3): 284-298.

Geiger, Marshall A, Rama Dasaratha V. (2003) Audit Fees, Nonaudit Fees, and Auditor Reporting on Stressed Companies. Auditing: A journal of Practice \& Theory. 22 (2) 17-53. 
Grant, Julia, Robert Bricker and Rimma Shiptsova. (1996) Audit Quality and Profesional Self-Regulation; A Social Dilemma Perspective and Laboratory Investigation, Auditing; A Journal of Practice and Theory. 15 (1) Spring.

Halim Alamsyah. (2011) Deputi Bank Indonesia. Akuntan Online. [31/08/2011].

Hay. David and David Davis. (2002) The Voluntary Choice of An Audit of Any Level of Quality: Auditing: A Journal of Practice and Theory. 23 (2).

Hayes, R., Wallage, P., \& Görtemaker, H. (2014) Principles of Auditing: An Introduction to International Standars on Auditing. United Kingdom: Pearson Education Limited.

Herawaty, A., \& Susanto, Y.K. (2009) Pengaruh Profesionalisme, Pengetahuan Mendeteksi Kekeliruan, dan Etika Profesi terhadap Pertimbangan Tingkat Materialitas Akuntan Publik. Jurnal Akuntansi dan Keuangan, 11 (1): 13-20.

Houghton, K.A., Jubb, C., \&Kend, M. (2011) Materiality in the context of audit: the real expectations gap. Managerial Auditing Journal. 26 (6): 482-500.

Ida Suraida. (2005) Pengaruh Etika, Kompetensi, Pengalaman Audit dan Resiko Audit Terhadap Skeptisme Profesional Auditor dan Ketepatan Pemberian Opini Akuntan Publik. Sosiohumaniora's blog. Jurnal Ilmu-ilmu Sosial dan Humaniora. 7 (3) November.

Institut Akuntan Publik Indonesia. (2011) Standar Profesional Akuntan Publik. Jakarta: Salemba Empat.

Jackson, Andrew B. Molderich, Michael and Roebuck, Peter. (2008) Mandatory Audit Firm Rotation and Audit Quality. Managerial Auditing Journal, 23 (5): 420-437.

Kharismatuti, Norma dan P Basuki Hadiprajitno (2012) Pengaruh Kompetensi dan Independensi Terhadap Kualitas Audit Dengan Etika Auditor Sebagai Variabel Moderasi. Diponegoro Journal Of Accounting. 1 (1) Desember.

Kieso, D.E., Weygandt, J.J., \& Warfield, T.D. (2011) Intermediate Accounting: IFRS Edition. Vol.1, United States of America: John Wiley \& Sons, Inc.

Kinanti, Anesia Putri (2013) Pengaruh Kompetensi, Independensi dan Motivasi Auditor terhadap Pertimbangan Tingkat Materialitas dalam suatu Pengauditan Laporan Keuangan. Jurnal Ilmiah Mahasiswa FEB, 1 (2): 58-72

Lestari, N.M.A., \&Utama, I.M.K. (2013) Pengaruh Profesionalisme, Pengetahuan Mendeteksi Kekeliruan, Pengalaman, Etika Profesipada Pertimbangan Tingkat Materialitas. E-Jurnal Akuntansi Universitas Udayana.. 5 (1): 78-92

Manita, R., Lahbari, H., \& Elommal, N. (2011) The Impact of Qualitative Factors on Ethical Judgments of Materiality: An Experimental Study with Auditors. International Journal of Business. 16 (3): 350-365

Mayangsari Sekar. (2003) Pengaruh Keahliaan dan Independensi Terhadap Pendapat Audit: Sebuah Kuasi Eksperimen. Jurnal Riset Akuntansi Indonesia. 6 (1).

Mc. Enroe, Jhon E and Martens, Stanley. (2001) Auditor and Investor Perceptions of The Expectation Gap. Accounting Horizons. 15 (4): 345 - 358.

Messier, W.F., Glover, S.M., \& Prawitt, D.F. (2014) Jasa Audit dan Assurance: Pendekatan Sistematis. Edisi 8. Jakarta: Salemba Empat.

Minanda, Reza dan Dul Muid. (2013) Analisis Pengaruh Profesionalisme, Pengetahuian Mendeteksi Kekeliruan, Pengalaman Bekerja Auditor, dan Etika Profesi Terhadap Pertimbangan Tingkat Materialitas Akuntansi Publik. Diponegoro Journal of Accounting, 1 (1): 1-8.

Mulyadi. (2013) Auditing. Edisi 6. Buku 1. Jakarta: Salemba Empat. 
Nirmala, R.P.A., dan Cahyonowati, N. (2013) Pengaruh Independensi, Pengalaman, Due Professional Care, Akuntabilitas, Kompleksitas Audit, dan Time Budget Pressure Terhadap Kualitas Audit (Studi Empiris pada Auditor KAP di Jawa Tengah dan DIY).Diponegoro Journal of Accounting. 2 (3): 1-13.

Nur Barizah Abu Bakar, Abdul Rahim Abdul Rahman, and Hafiz Majdi Abdul Rashid. (2005) Factors Influencing Auditor Independence: Malaysian Loan Officiers. Managerial Auditing Journal, 22 (6): 566 - 589.

Priyatno, D. (2014) SPSS 22 Pengolah Data Terpraktis. Yogyakarta: CV. Andi Offset.

Raiyani, Ni Luh Kadek puput Raiyani dan Saputa. (2014) Pengaruh Kompetensi, Kom[leksitas Tugas, dan Locus Of Control Terhadap Audit Judgement. E- Jurnal Akuntansi Universitas Udayana, 6 (3)

Shafie et al. (2009) Audit Firm Tenure and Audit Reporting Quality:Evidence in Malaysia. International Business Research, 2 (2): 99-109.

Sinaga, M., \&lsgiyarta, J. (2012) Analisis Pengaruh Profesionalisme terhadap Tingkat Materialitas dalam Proses Pengauditan Laporan Keuangan (Studi Empiris pada Auditor Eksternal di Kota Semarang).Diponegoro Journal of Accounting, 1 (2): 110.

Susanti Novie Suseno (2013) The Influence Of Independence, Size Of Public Accountant Office Toward Audit Quality And Its Impact On Public Accountant Office Reputation. International Jurnal of Scientific \& Technology Research, 2(3): 123126.

(2013) An Empirical Analysis of Auditor Independence and Audit Fees on Audit Quality. International Journal of Management and Business Studies, 3 (1): 8287.

Samelson, Donald, Suzanne Lowensohn and Laurance E Jhonson. (2006) The Determinants of Percieved Audit Quality and Auditee Satisfaction in Local Government. Journal of Public Bugeting, Accounting \& Financial Management, pg.139-166.

Singgih, E.M., \& Bawono, I.R. (2010) Pengaruh Independensi, Pengalaman, Due professional care, dan Akuntabilitas Terhadap Kualitas Audit (Studi pada Auditor di KAP "Big Four" di Indonesia). Simposium Nasional Akuntansi XIII Purwokerto 2010.

Sugiyono (2015) Statistika untuk Penelitian. Bandung: Alfabeta.

Sujarweni, V.W. (2014) Metodologi Penelitian: Lengkap, Praktis, dan Mudah Dipahami. Yogyakarta: Pustaka Baru Press.

Suryanita Winingtyas, et al. (2006) Penghentian Prematur Atas Prosedur Audit. Simposium Nasional Akuntansi IX Padang.

Institut Akuntan Publik Indonesia. (2011) Standar Profesional Akuntan Publik. Jakarta: Salemba Empat.

Tjandrawinata, C.L., \& Pudjolaksono, E. (2013) Pengaruh Profesionalisme Auditor Terhadap Pemahaman Tingkat Materialitas dalam Pemeriksaan Laporan Keuangan pada Kantor Akuntan Publik di Surabaya.Calyptra: Jurnal Ilmiah Mahasiswa Universitas Surabaya. 2 (1)

Tuanakotta, T.M. (2014) Berpikir Kritis dalam Auditing. Jakarta: Salemba Empat. Audit Berbasis ISA (International Standar on Auditing). Jakarta: Salemba Empat.

Veronica Sylvia Siregar, Fitriani, Arie Wibowo dan Viska Anggraita (2011) Rotasi dan Kualitas Audit: Evaluasi Atas Kebijakan Menteri Keuangan KMK No. 
423/KMK.6/2002 Tentang Jasa Akuntan Publik. Jurnal Akuntansi dan Keuangan Indonesia, 8 (1): 1-20.

Zikmund, W.G., Babin, B.J., Carr, J.C., \& Griffin, M. (2013) Business Research Methods.Ninth International Edition. South - Western: Cengage Learning. 